\title{
Antagonistic Potential and Molecular Characterization of Trichoderma spp. against Rhizoctonia solani Infecting Ghost Pepper in Manipur, India
}

\author{
Khedarani Koijam and Bireswar Sinha*
}

Department of Plant Pathology, Central Agricultural University, Iroisemba-795004, India

*Corresponding author

\section{Keywords \\ Biocontrol, Mass production, Screening \\ Article Info \\ Accepted: \\ 18 January 2018 Available Online: 10 February 2018}

\section{A B S T R A C T}

The present study was undertaken to analyze the effect of the native Trichoderma spp., isolated from the rhizosphere of ghost pepper (Capsicum chinense) against root rot caused by Rhizoctonia solani. Rhizospheric Trichoderma spp. were isolated from ghost pepper growing sites of Manipur and screened for their biocontrol potential against Rhizoctonia solani. Four fungal isolates were isolated and selected based on morphology and growth pattern. Molecular identification was carried out and an amplicon size of 262 bp were generated for fungus. Screening of the potent isolates showed variation on the radial growth of the pathogen, Rhizoctonia solani. Seven different substrates viz. Rice bran, Rice bran + Sugarcane juice $(10 \%)$, Rice bran+Cowdung (1:1)+Jaggery (3\%), Rice bran+ Cowdung (1:1)+Sugarcane juice (10\%), Rice bran+Sugar (3\%), Rice bran+ Mustard cake $(1: 1)$ + Jaggery (3\%), Rice bran+ Mustard cake (1:1) + Sugarcane juice (10\%) were evaluated for mass production of the most potent Trichoderma spp. Among the different substrate, highest population was recorded in rice bran + mustard cake $(1: 1)+$ sugarcane juice $(10 \%)$ from CAU $\left(13.33 \times 10^{8} \mathrm{cfug}^{-1}\right)$ isolate at 30 days of incubation.

\section{Introduction}

Bhut jolokia (Capsicum chinense Jacq.) is one of the world's hottest chilli entered in the Guinness book of world record (2006). Many pest and diseases ruined Bhut jolokia and among them damping-off disease of seedling as well root and stem rot in young transplants caused by Rhizoctonia solani is one of the important limiting factor in cultivation and production (Ngullie and Daiho, 2013). Even though numbers of crop plant diseases are managed by chemicals it causes degradation of beneficial microbes in the soil, physiological resistance in the pathogen and pollution. To keep away from such problems and combat of plant pathogens, use of biocontrol agents becomes necessary.

The idea of biological control of soil borne pathogen was advanced by Weindling (1932), on the antagonism by $T$. viride against soil fungi like Rhizoctonia, Pythium, Phytophthora, Sclerotium. Trichoderma performs very well against several plant pathogens in green house as well as in the field conditions therefore it could be an alternative or supplement to chemical 
fungicides (Mathivan et al., 2000). The commercial success of the biocontrol agents (BCA) depends upon the bio efficacy, shelf life and quick but easy multiplication on suitable, readily available and economical substrate (Kumar et al 2014). Substrates like cranberry processing waste (Zheng and Shetty 1998), com fibre dry mass (Vlaev et al., 1997) and sewage compost (Cotxarrera et al., 2002) are successfully used. A variety of organic sources such as agricultural waste and byproducts are reported to support the growth of BCA (Kousalya and Jeyarajan 1990). Agricultural wastes like coffee husks and farmyard manure are commonly used (Sawant and Sawant 1990; Bhai et al., 1994). Microorganisms isolated from the root or rhizosphere of specific crop better adapted to that crop and provides better control of diseases than organisms originally isolated from other plant species (Cook, 1993). Therefore the present work was undertaken to characterized, screen and mass multiplication of Trichoderma sp. isolated from rhizosphere region of ghost pepper

\section{Materials and Methods}

\section{Sample collection}

The soil samples were collected from different sites of Manipur. The soil was air dried under shade and kept sealed in cloth bag into refrigerator at $4^{\circ} \mathrm{C}$ for subsequent use whenever required.

\section{Cultural characteristics of Trichoderma spp.}

The cultural characteristics of Trichoderma were studied in potato dextrose agar (PDA). Mycelial discs $(6 \mathrm{~mm})$ of young growing culture of isolate of Trichoderma was inoculated centrally into the petriplates containing solidified PDA and incubated at 28 $\pm 1^{\circ} \mathrm{C}$ for one week (Gams and Bisset 1998).
Conidiophores, phialides and conidia of isolated Trichoderma was observed under the phase contrast microscope and its length was also measured with the help of Image analysis biowizard software (Fig. 1). The experiment was replicated three times.

\section{Molecular identification of the fungal isolates}

\section{Genomic DNA extraction of fungus}

Total genomic DNA of the fungal cultures was isolated using the HiPurA DNA isolation Kit (HiMedia, India).

\section{PCR amplification of ITS1 and ITS2 of nuclear ribosomal gene}

ITS region was amplified using specific ITS1 and ITS2 primers. ITS1 5'- TCC GTA GGT GAA CCT GCG G - 3'

ITS2 5'- GCT GCG TTC TTC ATC GAT GC $-3^{\prime}$

DNA amplification was carried out in Thermo electron corporation PCR. Approximately 262 nucleotides were amplified using PCR and were confirmed by $1.2 \%$ agarose gel electrophoresis (Kumar and Shukla 2005). The ITS rDNA sequence homologies were examined by comparing the sequences obtained with those available in the database of the National Centre for Biotechnology Information (NCBI) GenBank. Sequences were aligned using the CLUSTAL W software for phylogenetic analysis. Neighborjoining method was used for construction of phylogenetic tree using MEGA 4.0.1 with 500 bootstrap pseudoreplicates (Fig. 2).

\section{Dual culture experiment}

Antagonistic efficacy of Trichoderma spp. was tested against the isolated pathogenic fungi by dual culture experiment (Sangeetha 
et al., 2009). Trichoderma spp. and test fungi which were previously identified in our laboratory were inoculated $6 \mathrm{~cm}$ apart. Three replicates were maintained for each treatment and incubated at $28 \pm 2{ }^{\circ} \mathrm{C}$ for 7 days. Monoculture plates of both served as control. Seven days after incubation (DAI), radial growth of test fungi and Trichoderma spp were measured. Colony diameter of test fungi in dual culture plate was observed and compared with control. Percentage of radial growth inhibition (\% RGI) was calculated by using the formula: $100 \times[\mathrm{C}-\mathrm{T} / \mathrm{C}]$,

Where $\mathrm{C}=$ growth in control and $\mathrm{T}=$ growth in treatment.

\section{Mass production}

Trichoderma asperellum (CAU) and Trichoderma sp. (LAI2) was mass multiplied in Rice bran, Rice bran + Sugarcane juice (10\%), Rice bran+ Cowdung (1:1)+Jaggery (3\%), Rice bran+ Cowdung (1:1)+Sugarcane juice (10\%), Rice bran+Sugar (3\%), Rice bran+ Mustard cake (1:1) + Jaggery (3\%), Rice bran+ Mustard cake (1:1) + Sugarcane juice $(10 \%)$

\section{Results and Discussion}

For the soil samples collected from Thoubal, the plate counts yielded $2 \times 10^{2} \mathrm{CFU}$ per gm (dry weight) of soil, Lairikyengbam $1,3 \times 10^{2}$ CFU per gm (dry weight) of soil. Lairikyengbam 2, 2.3 $\times 10^{2} \mathrm{CFU}$ per gm (dry weight) of soil and CAU, 2.4x $10^{2} \mathrm{CFU}$ per gm (dry weight) of soil. A concentric ring with dense growth at the margin of the colony on PDA was observed. Variation among the conidiophores, phialides and conidia size of isolated Trichoderma sp. was observed (Table 1). A total of 4 isolates were characterized from the rhizosphere region of ghost pepper and distributed to 2 different species. Genbank accession numbers have been obtained for the ITS rRNA gene nucleotide sequences (Table 2).

\section{In vitro antagonistic activity of fungus}

A comparison of the data presented in Table 3 indicates that the 4 Trichoderma isolates tested in vitro, were effective in suppressing $R$. solani. Maximum inhibition percentage of 94.11 was obtained for CAU isolate (Fig. 3) while a least minimum inhibition was obtained from Lairikyengbam1 and Thoubal (78.82\%). Lairikyengbam 2 reduced the growth of the pathogen by more than $80 \%$ within 6 days of inoculation.

\section{Mass production of fungus}

Results from the Table 4 showed that among the different substrates tested, rice bran + mustard cake $(1: 1)+$ sugarcane juice $(10 \%)$ showed the highest growth of CAU (13.33 x $10^{8} \mathrm{cfug}^{-1)}$ at 30 days of incubation which was followed by rice bran + mustard cake $(1: 1)+$ jaggery $(3 \%)\left(12.20 \times 10^{8} \mathrm{cfu} \mathrm{g}^{-1}\right)$, rice bran + sugar $(3 \%)\left(9.60 \times 10^{8} \mathrm{cfu} \mathrm{g}^{-1}\right)$, rice bran $(6.03$ $\left.\mathrm{x} 10^{8} \mathrm{cfu} \mathrm{g}^{-1}\right)$, rice bran + cowdung $(1: 1)+$ sugarcane juice $(10 \%)\left(3.30 \times 10^{8} \mathrm{cfu} \mathrm{g}^{-1}\right)$, rice bran + cowdung $(1: 1)+\operatorname{jaggery}(3 \%)$ $\left(2.97 \times 10^{8} \mathrm{cfu} \mathrm{g}^{-1}\right)$, rice bran + sugarcane juice $(10 \%)\left(0.67 \times 10^{8} \mathrm{cfu} \mathrm{g}^{-1}\right)$ respectively. Rice bran+ Mustard cake $(1: 1)+$ Sugarcane juice (10\%) showed highest growth at 60 days of incubation which was followed by rice bran + Cowdung (1:1) + Jaggery (3\%) and rice bran $+\operatorname{sugar}(3 \%)\left(0.20 \times 10^{8} \mathrm{cfu} \mathrm{g}^{-1}\right)$ while the lowest growth was obtained from rice bran + sugarcane juice $(10 \%)\left(0.07 \times 10^{8} \mathrm{cfu} \mathrm{g}^{-1}\right)$. On the other hand, LAI2 at 30 days, growth rate was highest in rice bran + sugar $(3 \%)$ $\left(2.10 \times 10^{8} \mathrm{cfu} \mathrm{g}^{-1}\right)$ followed by rice bran $(0.90$ $\left.\mathrm{x} 10^{8} \mathrm{cfu}^{-1}\right)$, rice bran + sugarcane juice $(10 \%)\left(0.50 \times 10^{8} \mathrm{cfu} \mathrm{g}^{-1}\right)$, rice bran + mustard cake $(1: 1)+$ sugarcane juice $(10 \%)\left(0.47 \times 10^{8}\right.$ cfu $\left.^{-1}\right)$, rice bran + cowdung $(1: 1)+$ jaggery $(3 \%)\left(0.13 \% \times 10^{8} \mathrm{cfu}^{-1}\right)$, rice bran + 
cowdung (1:1) + sugarcane juice (10\%) $(0.05$ x $\left.10^{8} \mathrm{cfu} \mathrm{g}^{-1}\right)$. Rice bran + mustard cake $(1: 1)$ + jaggery $(3 \%)$ does not showed any population growth at 30 days of incubation. At 60 days incubation of LAI2, Rice bran+ Mustard cake (1:1) + Jaggery (3\%) $\left(0.6 \times 10^{8}\right.$ cfu $\mathrm{g}^{-1}$ ) showed highest population growth rate while population growth rate of Rice bran+ Cowdung (1:1)+Jaggery (3\%), rice bran + mustard cake $(1: 1)+$ sugarcane juice
(10\%), rice bran + cowdung $(1: 1)+$ sugarcane juice $(10 \%)$, rice bran $+\operatorname{sugar}(3 \%)$, rice bran + sugarcane juice $(10 \%)$ and rice bran were $0.20 \times \times 10^{8} \mathrm{cfu} \mathrm{g}^{-1}, 0.17 \times 10^{8} \mathrm{cfu} \mathrm{g}^{-1}$, $0.10 \times 10^{8}$ cfu g $^{-1}, 0.10 \times 10^{8}$ cfu g $^{-1}, 0.07 \times 10^{8}$ cfu $\mathrm{g}^{-1}$ and $0.03 \times 10^{8} \mathrm{cfu} \mathrm{g}^{-1}$ respectively. Population growth rate of both CAU (Fig. 4) and LAI2 were highest at 30 days of incubation.

Table.1 Anamorphic characteristics of Trichoderma isolates

\begin{tabular}{|c|c|c|c|c|}
\hline Sl.no. & Trichoderma spp. & $\begin{array}{l}\text { Phialides } \\
(\mu \mathrm{m})\end{array}$ & $\begin{array}{l}\text { Phialospores } \\
(\mu \mathrm{m})\end{array}$ & $\begin{array}{l}\text { Conidiophores } \\
(\mu \mathrm{m})\end{array}$ \\
\hline 1. & THOU & $4.2-7.8 \times 2.2-3.5$ & $2.0-2.8 \times 1.4-2.7$ & $5.2-26.7 \times 3.1-4.9$ \\
\hline 2. & LAI1 & $4.0-7.7 \times 2.3-3.6$ & $2.2-3.7 \times 1.3-2.0$ & $5.3-32.3 \times 2.7-3.6$ \\
\hline 3. & LAI2 & $3.6-7.9 \times 1.3-1.6$ & $1.9-2.3 \times 1.7-2.5$ & $4.7-28.2 \times 3.0-4.5$ \\
\hline 4. & CAU & $3.9-8.1 \times 2.4-3.7$ & $1.8-2.7 \times 1.5-2.3$ & $4.8-29.3 \times 4.3-5.5$ \\
\hline
\end{tabular}

Table.2 Closest match of fungal isolates based on ITS gene phylogeny analysis

\begin{tabular}{|c|l|l|l|}
\hline Isolate & \multicolumn{1}{|c|}{ Closest species } & \multicolumn{1}{|c|}{$\begin{array}{c}\text { Similarity } \\
\text { percentage }\end{array}$} & $\begin{array}{c}\text { Accession } \\
\text { number }\end{array}$ \\
\hline CAU & Trichoderma asperellum & 99.8 & KX373484 \\
\hline LAI1 & Trichoderma asperellum & 99.7 & KX373485 \\
\hline LAI2 & Trichoderma sp. & 99.6 & KX373486 \\
\hline THOU & Trichoderma harzianum & 99.9 & KX373487 \\
\hline
\end{tabular}

Table.3 Evaluation of Trichoderma spp. against $R$. solani

\begin{tabular}{|c|c|c|}
\hline Isolate & $\begin{array}{l}\text { Radial growth of } R \text {. solani } \\
(\mathrm{cm})\end{array}$ & \% Inhibition \\
\hline LAI1 & 1.8 & 78.82 \\
\hline THOU & 1.8 & 78.82 \\
\hline LAI2 & 1.3 & 84.70 \\
\hline CAU & 0.5 & 94.11 \\
\hline
\end{tabular}


Table.4 Effect of different substrates on the population of Trichoderma spp. CAU and LAI2

\begin{tabular}{|c|c|c|c|c|}
\hline \multirow{3}{*}{ Treatments } & \multicolumn{4}{|c|}{$\begin{array}{l}\text { Mean population }\left(\times 10^{8} \mathrm{cfu} / \mathrm{g}\right) \text { at } 30 \& 60 \text { days of inoculation } \\
(\mathrm{n}=3)\end{array}$} \\
\hline & \multicolumn{2}{|c|}{30 DAYS } & \multicolumn{2}{|c|}{60 DAYS } \\
\hline & CAU & LAI2 & CAU & LAI2 \\
\hline T1 Rice bran & 6.03 & 0.90 & 0.10 & 0.03 \\
\hline $\begin{array}{l}\text { T2. Rice bran + Sugarcane } \\
\text { juice }(10 \%)\end{array}$ & 0.67 & 0.50 & 0.07 & 0.07 \\
\hline $\begin{array}{l}\text { T3. Rice bran+ Cowdung } \\
(1: 1)+\text { Jaggery }(3 \%)\end{array}$ & 2.97 & 0.13 & 0.20 & 0.20 \\
\hline $\begin{array}{l}\text { T4. Rice bran+ Cowdung } \\
\text { (1:1)+Sugarcane juice }(10 \%)\end{array}$ & 3.30 & 0.05 & 0.10 & 0.10 \\
\hline T5. Rice bran+Sugar (3\%) & 9.60 & 2.10 & 0.20 & 0.10 \\
\hline $\begin{array}{l}\text { T6. Rice bran+ Mustard } \\
\text { cake }(1: 1)+\text { Jaggery }(3 \%)\end{array}$ & 12.20 & 0.00 & 0.17 & 0.60 \\
\hline $\begin{array}{l}\text { T7. Rice bran+ Mustard } \\
\text { cake }(1: 1)+\text { Sugarcane juice } \\
(\mathbf{1 0 \%})\end{array}$ & 13.33 & 0.47 & 0.21 & 0.17 \\
\hline
\end{tabular}

Fig.1 Microscopic observation of Trichoderma sp

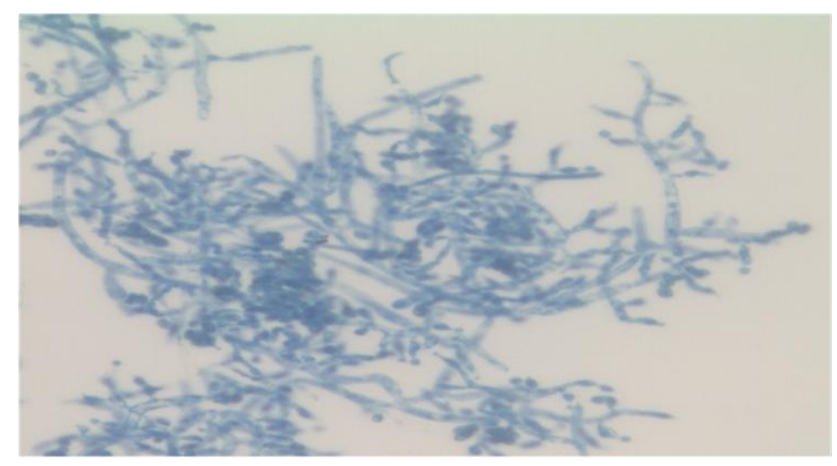

Fig.2 Phylogenetic tree of fungus from rhizosphere region of ghost pepper

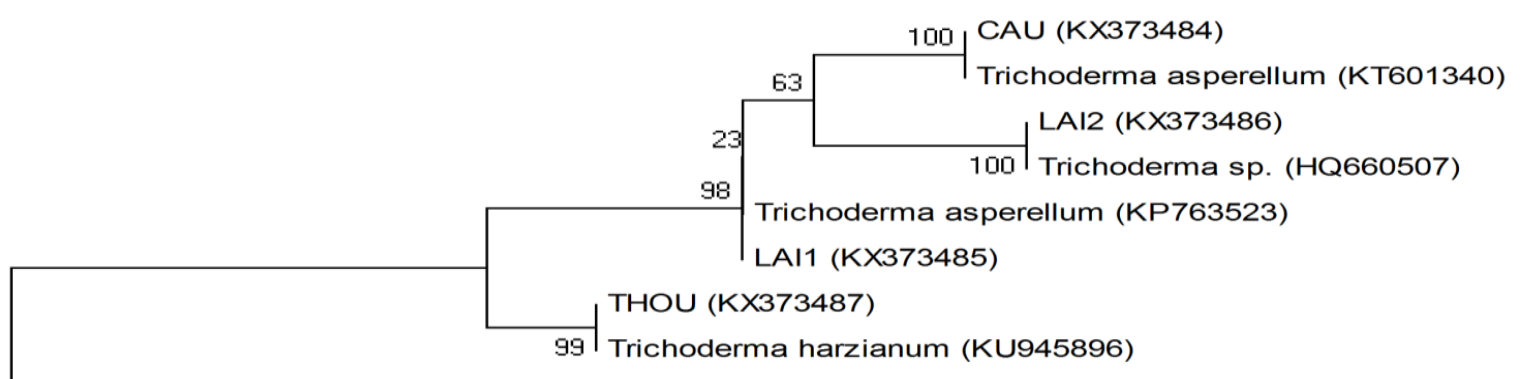


Fig.3 Test for antagonistic activity of fungal isolate against Rhizoctonia solani

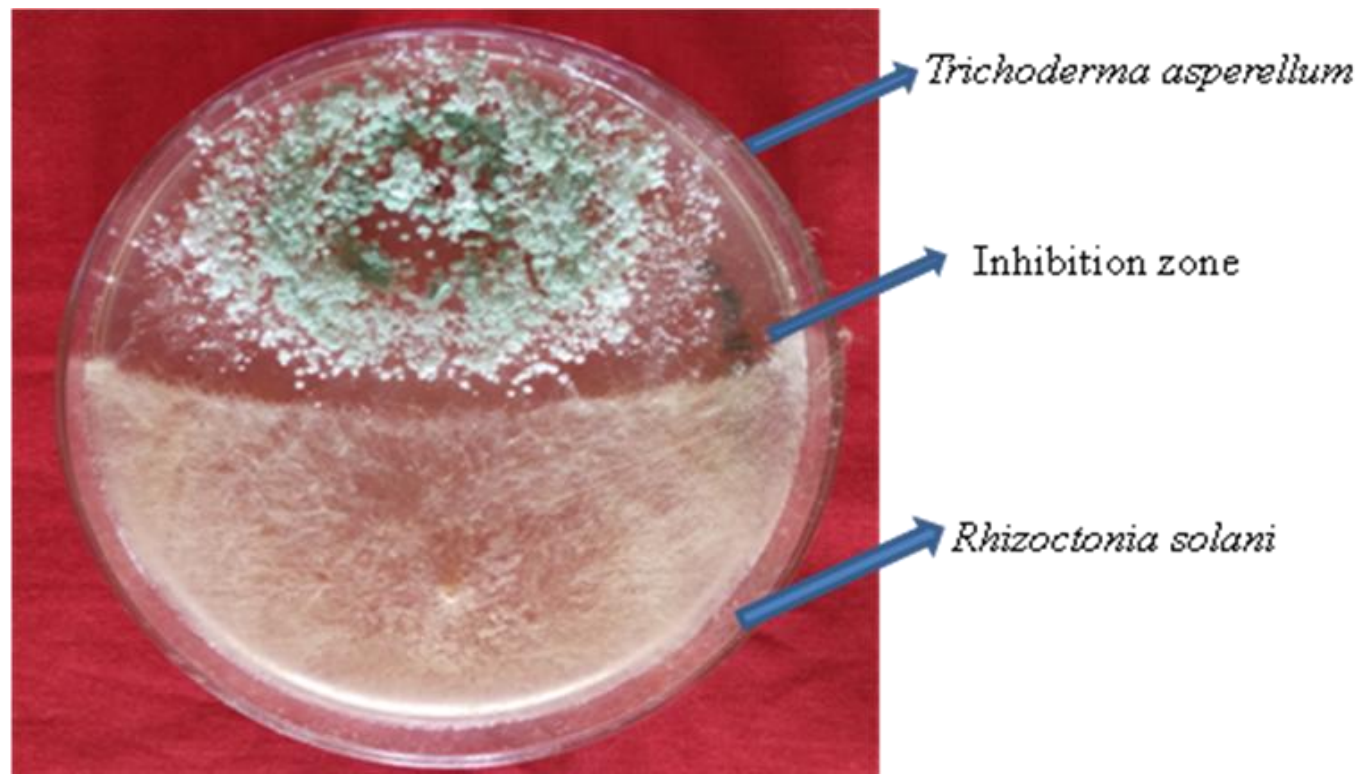

Fig.4 Mass production of native Trichoderma

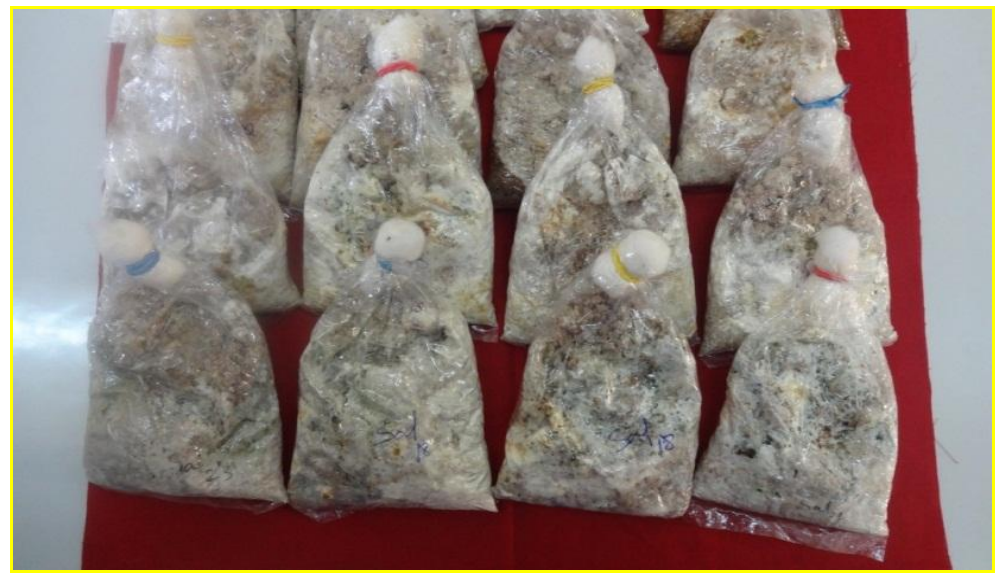

Trichoderma spp. was used as successful biocontrol agent against $P$. capsici, causal organism of quick wilt of black pepper (Sarma et al., 1994). Trichoderma harzianum has revealed as a biocontrol agent of $R$. solani in chilli which is in accordance to the report of Bunker and Mathur, 2001. Muhyi and Bosland (1992) have reported T. harizanum for the control of damping off disease in chilli plants caused by $R$. solani and furthermore to enhance the growth of the plants. In dual culture experiment $T$. harzianum was found to be inhibitory in nature against soil borne fungal pathogens of chickpea viz, Rhizoctonia solani, Sclerotium rolfsii and $F$. oxysporum (de Melo and Faull, 2000; Rudresh et al., 2005). Trichoderma species are the most promising in controlling foliar and root diseases in a wide range of agricultural crops (Elad, 2000; Mathivanan et al., 2004). T. asperellum isolate CGMCC 6422 is a valuable biocontrol agents for controlling pepper blight (Jiang et al., 2016). Inhibition of $R$. solani by $T$. harzianum, T. viride and $T$. aureoviride is reported by Shalini and Kotasthane, 2007. T. harzianum and T. viride 
were effective biocontrol agent for the management of Wilt/ Root Rot and Dampingoff Diseases in Chilli (Capsicum annuum) (Dar et al., 2015). Trichoderma sp. inhibits pathogenic invasion through the phenomenon of parasitism, antibiotics, competition, lysis of pathogenic hyphae, production of organic metabolites like enodin, chitinase and volatile inhibitory substance like acetaldehyde (Bunkar and Kusum, 2001).

An increased growth and biomass production of Trichoderma isolates between $25^{\circ} \mathrm{C}$ and $30^{\circ} \mathrm{C}$ was observed by Malathi and Doraiswami (2003). Rini and Sulochana (2006) isolated Trichoderma and Fluorescent pseudomonads (Pseudomonas fluorescens P28 and P51) were evaluated under green house and field conditions for efficacy in suppressing Rhizoctonia root-rot incidence and promoting plant growth in chilli. Pandey and Pandey (2003) found that the agricultural by-products like rice bran, rice husk and saw dust when mixed with sorghum in 1:1 ratio supported good growth and sporulation of $T$. harzianum and $T$. viride. Various organic substrates viz., rice bran, tea waste, decomposed coir pith and dried cow dung for the mass multiplication of $T$. viride were evaluated by Akila et al., (2007). T. viride population was highest on 20th day in sterilised tea waste waste $\left(236.30 \times 10^{6} \mathrm{cfu}\right)$, followed by rice bran $\left(152 \times 10^{6} \mathrm{cfu}\right)$, decomposed coir pith $\left(44.35 \times 10^{6} \mathrm{cfu}\right)$, talc $\left(36 \times 10^{6} \mathrm{cfu}\right)$ and dried cow dung $\left(20 \times 10^{6}\right.$ cfu). Tiwari et al., (2004) used sterilized rice bran as a substrate for the mass multiplication of $T$. viride with $88.51 \%$ spore viability.

CAU isolate when treated with Rice bran, Rice bran+ Mustard cake (1:1) + Jaggery (3\%), Rice bran+ Cowdung (1:1)+Jaggery (3\%), Rice bran+ Cowdung (1:1)+Sugarcane juice (10\%), Rice bran+Sugar (3\%), Rice bran + Sugarcane juice (10\%) population increased at 30 days of incubation and thereafter declined at 60 days of incubation which is similar to the report of Akila et al., (2007) where the population of $T$. viride has started increasing on $30^{\text {th }}$ days and then declined from $40^{\text {th }}$ days onwards. Likewise for LAI2 isolate population increased at 30 days of incubation and thereafter declined at 60 days of incubation when treated with Rice bran, Rice bran + Sugarcane juice (10\%), Rice bran+ Mustard cake (1:1) + Sugarcane juice (10\%), Rice bran+Sugar (3\%). The present study revealed that in vitro results obtained using dual culture technique suggest that Trichoderma asperellum and Trichoderma sp. LAI2 was the best at inhibiting the mycelial growth of Rhizoctonia solani. Thus it might be use as a potential biocontrol agent in future.

\section{Acknowledgement}

Authors acknowledge the financial support received from Department of Biotechnology, Government of India in the form of research grant.

\section{References}

Akilai R, Rajendran L, Saveetha K, Muthuivieena K, Salvliyappan R (2007) Effect of various organic substrates on the mass multiplication of Trichoderma viride. J. Bioi C. 21:313-316.

Bhai RS, Thomas J, Naidu R (1994) Evaluation of carrier media for the field application of Trichoderma sp. in cardamom growing soils. J Plant Crops. 22:50-52.

Bunkar RN, Kusum M (2001) Integration of biocontrol agents and fungicides for suppression of dry root rot of Capsicum fructescens. J Mycol Pl Pathol 31:330334.

Bunker RN, Mathur K (2001) Antagonism of local biocontrol agents to Rhizoctonia solani inciting dry root rot of chilli. $J$ 
Mycol Plant Pathol., 31:50-52.

Cook RJ (1993) Making greater use of introduced microrganisms for biological control of plant pathogens. Annu Rev Phytopathol., 31:53-80.

Cotxarrera L, Trillas-Gay MI, Steinberg C, Alabouvette C (2002) Use of sewage sludge compost and Trichoderma asperellum isolates to suppress Fusarium wilt of tomato. Soil Biol Biochem 34:467-476.

Dar GH, Mir GH, Rashid H, Dar WA, Majeed M (2015) Evaluation of microbial antagonists for the management of wilt/ root rot and damping-off diseases in chilli (Capsicum annuum). Vegetos, 28(4):102-110.

de Melo IS, Faull JL (2000) Parasitism of Rhizoctonia solani by strains of Trichoderma spp.. Sci Agric 57: 223277.

Elad Y (2000) Biological control foliar pathogens by means of Trichoderma harzianum and potential modes of action. Crop Protect 19:709-714.

fungal endophytes against

Gams W, Bisset J (1998) Morphology and identification of Trichoderma. In: Kubicek E, Harman GE (eds) Trichoderma and Gliocladium: basic biology, taxonomy and genetics, vol 1. Taylor and Francis, London, pp 3-34

Gangadharan K, Jeyarajan R (1990) Mass multiplication of Trichoderma sp. J Biol Control 4:70-71.

Guinness Book of World Records. 2006. Hottest Spice. www.guinnessworldrecords.com. Accessed 13 Sept. 2006.

Jiang H, Zhang L, Zhang J, Ojaghian MR, Hyde KD (2016) Antagonistic interaction between Trichoderma asperellum and Phytophthora capsici in vitro. J Zhejiang Univ Sc B 271-281. doi:10.1631/jzus.B1500243

Kousalya G, Jeyarajan R (1990) Mass multiplication of Trichoderma spp. $J$ Biol Control, 4:70-72.

Kumar S, Roy PD, Lal M, Chand G, Singh V (2014) Mass multiplication and self life of Trichoderma species using various agroproducts. The bioscan 9(3):11431145 (Supplement on Plant Pathology)

Kumar M, Shukla PK (2005) Use of PCR Targeting of Internal Transcribed Spacer Regions and Single-Stranded Conformation Polymorphism Analysis of Sequence Variation in Different Regions of rRNA Genes in Fungi for Rapid Diagnosis of Mycotic Keratitis $J$ Clin Microbiol, 43(2): 662-668.

Malathi P, Doraiswamy S (2003) Compatibility of Trichoderma harzianum with fungicides against Macrophomina phaseolina $\mathrm{Pl}$ Dis Res 18(2):139-143.

Mathivanan N, Prbavathy VR, Murugesan K (2004) Biocontrol potential of microorganisms - an overview: focus on Trichoderma as biofungicide for the management of plant diseases. In: Mayee CD, Manoharachary C, Tilak KVBR, Mukadam KS Deshpande J (eds) Biotechnological approaches for the integrated management of crop diseases, Daya, Delhi, pp 88-109

Mathivanan N, Srinivasan K, Chelliah S (2000) Biological control of soil-borne diseases of cotton, eggplant, okra and sunflower by Trichoderma viride. $J$ Plant Dis Protect 107(3):235-244.

Muhyi R, Bosland PW (1992) Evaluation of Capsicum germplasm for sources of resistance to Rhizoctonia solani. Hort Sci 30:341-342.

Ngullie M, Daiho L (2013) Efficacy of biocontrol agents in controlling Rhizoctonia solani on naga king chilli (Capsicum chinense Jacq.) JEBAS 1(3):198-201.

Pandey PK, Pandey KK (2003) Standardization of different growth 
materials, chemicals and carriers for antagonists. Abstracts of Research Papers (S.1 1) Indian Phytopath 56:351.

Rini CR, Sulochana KK (2006) Management of seedling rot of chilli (Capsicum annuum L.) using Trichoderma spp. and fluorescent pseudomonads (Pseudomonas fluorescens). J Trop AG 44 (1-2):79-82.

Rudresh DL, Shivaprakash MK, Prasad RD (2005) Effect of combined application of Rhizobium, phosphate solubilizing bacterium and Trichoderma spp. on growth, nutrient uptake and yield of chickpea (Cicer aritenium L.). Appl Soil Ecol 28:139-146. DOI: 10.1016/j.apsoil. 2004.07.005

Sangeetha A, Mohan S, Neelamegam R (2009) In vitro evaluation of fungal and bacterial antagonists against Colletotrichum falcatum Went. J Biol Control 23(3): 333-336

Sarma YR., Anandaraj M, Rajan PP (1994) Phytophthora, A threat to black pepper: Present status and future strategies of disease management. Spice India 7:10 13.
Sawant IS, Sawant SD (1990) Coffee fruit skin and cherry husk as substrates for mass multiplication of Trichoderma. harzianum an antagonist of citrus Phytophthora. Indian Phytopathol 42: 336(Abst.).

Shalini S, Kotasthane AS (2007) Parasitism of Rhizoctonia solani by strains of Trichoderma spp. EJEAF Chemistry 6:2272-2281.

Tiwari AK, Kumar K, Razdan VK, Rather TR (2004) Mass production of Trichoderma viride on indigenous substrates. Ann Plant Protect Sci 12:71-74.

Vlaev SD, Djejeva G, Raykovska V, Schugerl K (1997) Cellulase production by Trichoderma sp. Grown on corn fibre substrate. Process Biochem 32:561565.

Weindling R (1932) Trichoderma lignorum as a parasite of other soil fungi. Phytopathology, 22: 837-845.

Zheng Z, Shetty K (1998) Cranberry processing waste for solid state fungal inoculant production. Process Biochem $3: 323-329$.

\section{How to cite this article:}

Khedarani Koijam and Bireswar Sinha. 2018. Antagonistic Potential and Molecular Characterization of Trichoderma spp. against Rhizoctonia solani Infecting Ghost Pepper in Manipur, India. Int.J.Curr.Microbiol.App.Sci. 7(02): 2085-2093.

doi: https://doi.org/10.20546/ijcmas.2018.702.248 